\title{
Natural killer cell and large granular lymphocyte deficiency in the gut of children with inflammatory bowel disease
}

F HADZISElimovic, MD, LR EMmONS, PHD, U SCHAUB

\begin{abstract}
The occurrence of natural killer cells and large granular lymphocytes (LGL) within the epithelium of colonic mucosa in children with inflammatory bowel disease (IBD) was compared to normal controls. Their numbers and localization within the epithelium from various regions of the colon were analyzed with immunohistochemical techniques using fluorescent, light and electron microscopy. The average number of natural killer cells and LGL in normal controls was $3.0 \pm 1.1$ per $\mathrm{mm}^{2}$. In contrast, there were no natural killer cells in the gut epithelium of children with IBD, irrespective of disease activity, whether the biopsy specimens were obtained from involved or uninvolved inflammatory regions of the gut, or the treatment status of the patients. However, the number of natural killer cells was normal in patients in remission with left-sided colitis. The lack of natural killer cells and LGL in the gut epithelium in children with IBD may be indicative of a possible genetic predisposition. The authors also present a new therapeutic strategy consisting of low dose interferonalpha-2a that is efficacious in ameliorating ulcerative colitis and Crohn's disease and concomitantly increasing the number of natural killer cells and LGL in the gut. Can J Gastroenterol 1990;4(7):303-308 (pour résumé, voir page 304)
\end{abstract}

Key Words: Children, Gut epithelium, Inflammatory bowel disease, Interferonalpha-2a, Large granular lymphocytes, Natural killer cells

Department of Gastroenterology, Children's Hospital, University of Basel, Basel, Switzerland Correspondence and reprints: Professor Dr F Hadziselimovic, Basler Kinderspital, Römergasse 8, CH-4005 Basel, Switzerland
TNFLAMMATORY BOWEL DISEASE (IBD) is a chronic disease characterized by inflammatory cell infiltrates and severe histological alterations of the mucosa and submucosa of the gut. Neoplastic transformation has been documented in many of the cases. One possible cause of IBD may be a deficiency in antigen-specific suppressor $\mathrm{T}$ cell function (1). The number and activity of natural killer cells present in blood was significantly lower in ulcerative colitis and Crohn's disease patients than in normal individuals (2-4). Allogeneic mixed lymphocyte reactions were equivalent in both IBD patients and normal controls (5). In contrast, histological analyses of natural killer cells in colonic mucosa did not reveal any significant differences between patients with IBD and normal healthy controls (6). 


\section{Déficience en cellules tueuses (NK) et en LGL dans l'épithélium intestinale des enfants porteurs de maladies inflammatoires de l'intestin}

RESUME: La présence des cellules NK et des LGL dans l'épithelium de la muqueuse colique des enfants porteurs de maladies inflammatoires de l'intestin a été comparée à celle des contrôles normaux. Leurs nombres et leur situation à l'intérieur de l'épithélium de diverses régions du côlon ont été analysés à l'aide de techniques immunohistochimiques microscopie en fluorescence, photonique et électronique. Le nombre moyen de cellules NK chez les contrôles normaux était de 3,0 $\pm 1,1$ cellules/mm $\mathrm{mm}^{2}$. En comparaison, l'épithélium des enfants porteurs de MII ne comptait aucune cellule NK, indépendamment de l'activité de la maladie, du site de prélèvement des pièces de biopsie (segments inflammatoires atteints ou non) ou du statut de traitement des patients. Pourtant, le nombre de cellules NK était normal chez les patients en rémission porteurs de colite à prédominance gauche. L'absence de cellules NK dans l'épithélium de l'intestin des enfants atteints de MII semble trahir une prédisposition génétique possible. Les auteurs proposent une nouvelle stratégie thérapeutique consistant en de faible doses d'interféron alpha-2 - posologie qui améliore la CU et la maladie de Crohn tout en augmentant le nombre de cellules NK au niveau de l'intestin.

There is currently no evidence for a specific immunocytotoxic mechanism that can explain the destructive inflammatory process of IBD. The authors have investigated the location and distribution of the various immune cells in the gut of children with IBD; more especially, they have concentrated on natural killer cells. Light, fluorescent and electron microscopy was used to ascertain the in situ numbers and positions of natural killer cells in the gut.

\section{PATIENTS AND METHODS}

For the past several years, the authors have attended 16 children, aged two to 17 years, who had ulcerative colitis or Crohn's disease. Nine had active disease confirmed by clinical criteria and histological evidence; seven were in remission. Multiple biopsies were obtained at the time of surgery or colonoscopy of both involved and uninvolved regions of the gut. The 16 patients were compared with seven normal individuals.

The control individuals underwent a rectosigmoidoscopic procedure because of one of the following reasons: juvenile polyps, suspected neuronal intestinal dysplasia, or suspected neuronal ceroid lipofuscinosis. None had clinical symptoms of colitis; histological analyses also confirmed their normality.
Interferon-alpha-2a therapy: One patient, a 14-year-old girl, had been suffering from ulcerative colitis for two years. Her disease had recently progressed to pancolitis; she, therefore, was being considered for a colectomy. Her colitis activity index (CAI) was 18 ; the endoscopic activity index (EI) was 8 (8). She was placed on an interferonalpha-2a regimen of $3 \mathrm{MU} /$ day subcutaneously three times per week for three months during which time CAI and EI were closely monitored. Tissue biopsies were obtained from the rectal and sigmoid regions of the gut for histological and immunohistochemical evaluations at four and eight weeks following the initiation of interferonalpha-2a treatment.

Tissue processing: Tissues were obtained during endoscopic procedures from various regions of the gut of children with IBD. They were fixed either in $2 \%$ paraformaldehyde plus $0.1 \%$ glutaraldehyde (for semi-thin section immunohistochemical procedures), or $2 \%$ glutaraldehyde (for electron microscopic routines) in phosphate buffered saline (PBS) (0.15 M sodium chloride, $0.01 \mathrm{M}$ phosphate buffer, $\mathrm{pH}$ 7.3) for 1 to $2 \mathrm{~h}$ at room temperature. Tissue samples were then rinsed several times in PBS (10 mins each) and immersed in $0.05 \mathrm{M}$ ammonium chloride in PBS for 30 mins to neutralize the free aldehyde groups.
After rinsing three times in PBS (10 mins each), the tissue was dehydrated in graded ethanols and embedded in Epon 812 (9)

Semi-thin sections $(0.5$ to $1.5 \mu \mathrm{m})$ were mounted on polylysine-treated (1 $\mathrm{mg} / \mathrm{mL}$ for 5 mins) glass slides. The Epon was removed (not etched) according to Maxwell (10), following which the slides were immersed in Lugol's solution ( $1 \%$ iodine in $2 \%$ aqueous potassium iodide) for $5 \mathrm{mins}$, then washed thoroughly before rinsing in $2.5 \%$ aqueous sodium thiosulfate solu. tion for 3 mins. The slides were rinsed in gently running tap water for 5 mins, then transferred to distilled water.

Natural killer cells were identified immunohistochemically by means of a specific monoclonal antibody, antileucine-11 (Becton-Dickinson). The antibody was diluted $(1: 20)$ in $\mathrm{PBS}^{+++}$ ( $1 \%$ goat serum, $0.05 \%$ Tween 20 and $0.1 \%$ Triton-X). The primary antibody incubation was for $1.5 \mathrm{~h}$ at $25^{\circ} \mathrm{C}$. The slides were washed in PBS three times (10 mins each). A second antibody, polyvalent goat anti-mouse IgG (whole molecule) gold conjugate $10 \mathrm{~nm}$ (Sigma Chemical Co, Missouri) was diluted (1:50) in $\mathrm{PBS}^{+++}$and incubated and processed in the manner described for the primary antibody.

The gold particles were visualized with a light microscope by means of a silver enhancement procedure (Sigma Chemical Co, Missouri).

Alternatively, the cells were identified directly with a fluorescent micro. scope after incubation with either a primary monoclonal antibody directed against leucine-11, conjugated with a fluorochrome (fluorescein isothio. cyanate conjugate), or identified in. directly with a second antibody, goat anti-mouse fluorescein isothiocyanate. conjugated antibody.

Photographs were taken with a Zeiss Photomicroscope III using Kodak TMAX 400 film with phase contrast ob. jectives plus a blue conversion filter. Electron microscopy: The grids with ultrathin sections were placed on drops of PBS (plus $1 \%$ bovine serum albumin) for 5 mins. The primary antibody (diluted 1:20) was then placed on the sections and incubated at room 


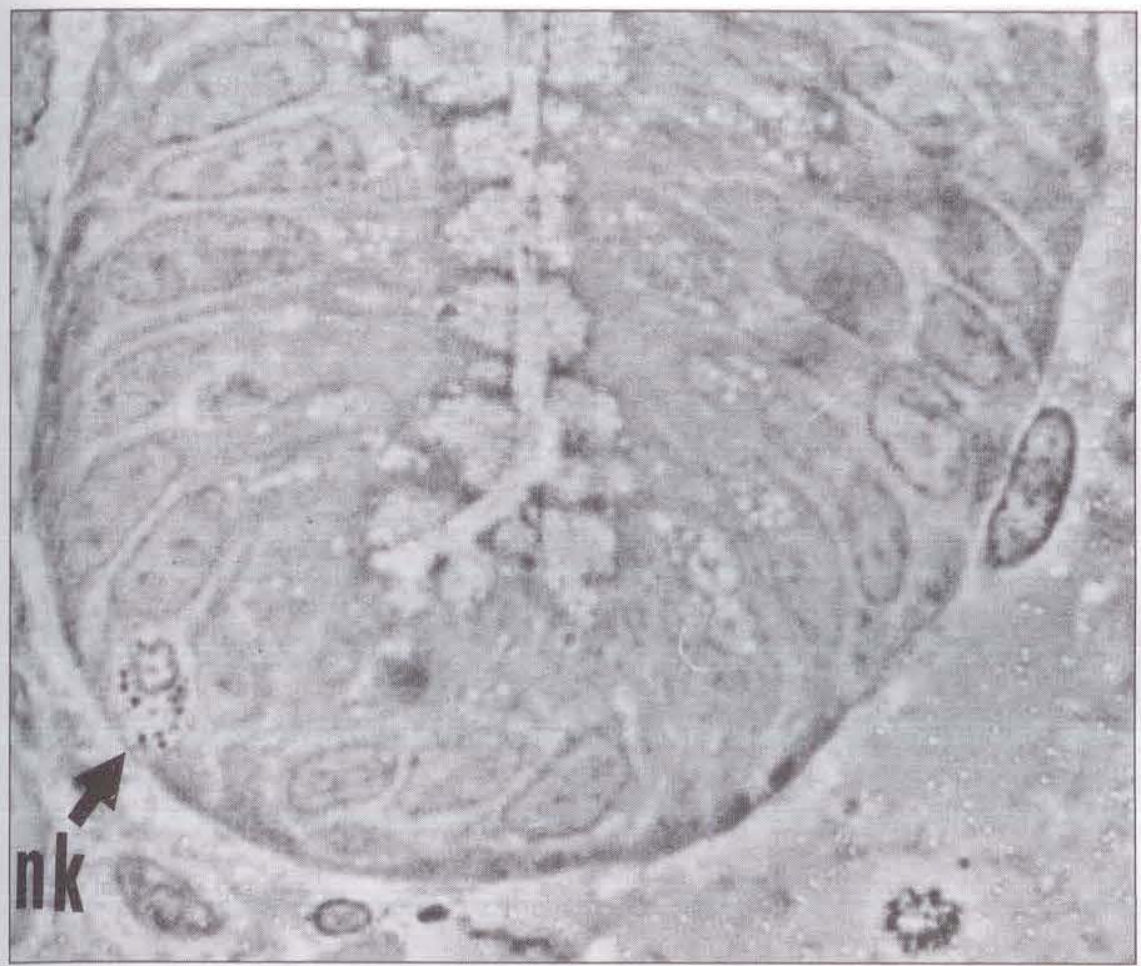

Figure 1) A natural killer cell ( $n k$ ) within the colonic epithelium of normal controls and in inflammatory bowel disease patients in remission. The anti-leucine-11 (CD16) antibody is labelled with a gold conjugate enhanced with silver $\times 1270$

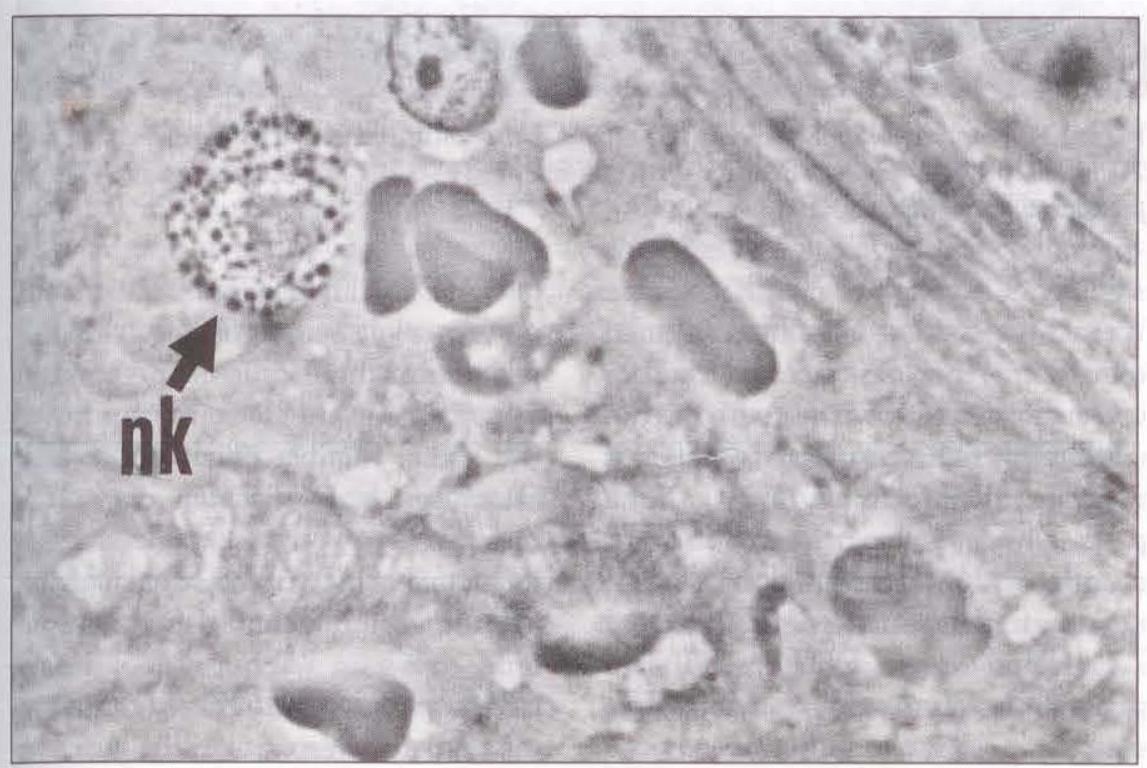

Figure 2) A natural killer cell ( $n k$ ) within the lamina propria of a control, and in all patients with inflammatory bowel disease. The anti-leucine-11 (CD16) is labelled with a gold conjugate enhanced with silver $\times 1250$

temperature for $1 \mathrm{~h}$. The grids were washed three times in PBS ( 3 mins each) and then incubated for $1 \mathrm{~h}$ with protein A conjugated with $20 \mathrm{~nm}$ gold at appropriate dilutions. The grids were washed in PBS ( $2 \times 2$ mins) and then counterstained with uranyl acetate $(3 \%$ in distilled water for 15 mins). Following two additional washes with distilled water ( 2 mins each), the sections were counterstained with lead citrate for 2 mins. A Zeiss electron microscope (EM 109) was used to examine and photograph the tissue sections.

\section{RESULTS}

Natural killer cells are characteristically large granular lymphocytes, mainly located within the epithelium and in the proximity of the basement membrane in controls. More often they are situated within the superficial epithelium rather than within the crypts of the gut.

When the natural killer cells were visualized with a monoclonal antibody that is specific for natural killer cells (anti-leucine-11, CD16), the labels were located within granules in the cytoplasm of the cells as well as on the surface of the cells, but they were never within the nucleus (Figures 1,2). Apparently the anti-leucine-11 (CD16) antigens had been internalized by the natural killer cells.

The fine structural analysis of natural killer cells revealed characteristic electron-dense granules scattered throughout the cytoplasm that were usually localized around the nuclear notch. Furthermore, at the ultrastructural level, the Golgi apparatus was prominent and surrounded by dense granules. Occasionally, microtubule organizing centres were found.

Within the epithelium of the control group, there were $3.0 \pm 1.1$ natural killer cells per $\mathrm{mm}^{2}$ (Table 1). None of the nine patients with IBD had natural killer cells located in the epithelium regardless of whether the tissue was normal or abnormal, nor whether it was obtained before the start of treatment $(n=2)$ or with relapse during treatment $(n=7)$ (Table 1). Of the seven patients who were in remission, three had no natural killer cells in the epithelium while four, including the 14-year-old girl, had $4.08 \pm 1.65$ natural killer cells per $\mathrm{mm}^{2}$ present. In this group of patients with natural killer cells, all had suffered originally from left-sided colitis, while those lacking natural killer cells had pancolitis during the active state of the disease. Natural killer cells were found in the lamina propria of the gut in all individuals, normal individuals and those with IBD (Figure 2). The 14-year-old girl who was treated with interferon-alpha-2a for a period of three months achieved clinical, radiologic and histologic 
TABLE 1 Distribution of natural killer (NK) cells
in inflammatory bowel disease (IBD)
patients and normal controls

\begin{tabular}{lclc}
$\begin{array}{l}\text { Patient } \\
\text { group }\end{array}$ & $\begin{array}{c}\text { No of } \\
\text { subjects }\end{array}$ & NK cells* & $\begin{array}{c}\% \\
\text { patients }\end{array}$ \\
\hline Controls & 7 & $3.04(1.1)$ & 100 \\
IBD & 9 & 0 & 0 \\
IBD- & 7 & $2.33(2.7)$ & 57 \\
remission & & & \\
\hline
\end{tabular}

"Mean number of $\mathrm{NK}$ cells per $\mathrm{mm}^{2}$ (SD). tPatients who have NK cells

remission after only six weeks of treatment. The CAI decreased from 18 to 2 while the EI went from 8 to 2 . These dramatic changes were confirmed endoscopically and by histological examinations of rectal biopsies obtained four and eight weeks after the start of the treatment. No ulcerations were detected, and only a few small crypt abscesses (occurring rarely) were observed during the first and second endoscopic procedures. Significant regenerative changes occurred following interferon-alpha-2a treatment. As early as four weeks following the commencement of treatment, the number of naturalkiller cells had increased to 4.5 cells per $\mathrm{mm}^{2}$ in the epithelium of the gut; the same number of cells was observed during the second biopsy procedure. This represented a significant increase in the number of natural killer cells in the epithelium compared with no cells observed initially.

The second patient had had Crohn's disease for the past 10 years with several relapses and two major surgeries. He was steroid-dependent and developed severe perianal lesions. Both intensive medical and surgical treatment were unsuccessful in ameliorating this perianal disease. Although he received steroids, metronidazole, an elemental diet and 5-aminosalicylic acid (5ASA) treatment in the past 1.5 years, he lost $10 \mathrm{~kg}$ of body weight and was admitted to hospital with a CDAI of 355 and histologically confirmed relapse. At entry, no natural killer cells were found within the colonic epithelium. Steroids, metronidazole and 5-ASA were discontinued and his normal diet supplemented with an elemental diet. Eight weeks after starting treatment with interferon-alpha- $2 a$

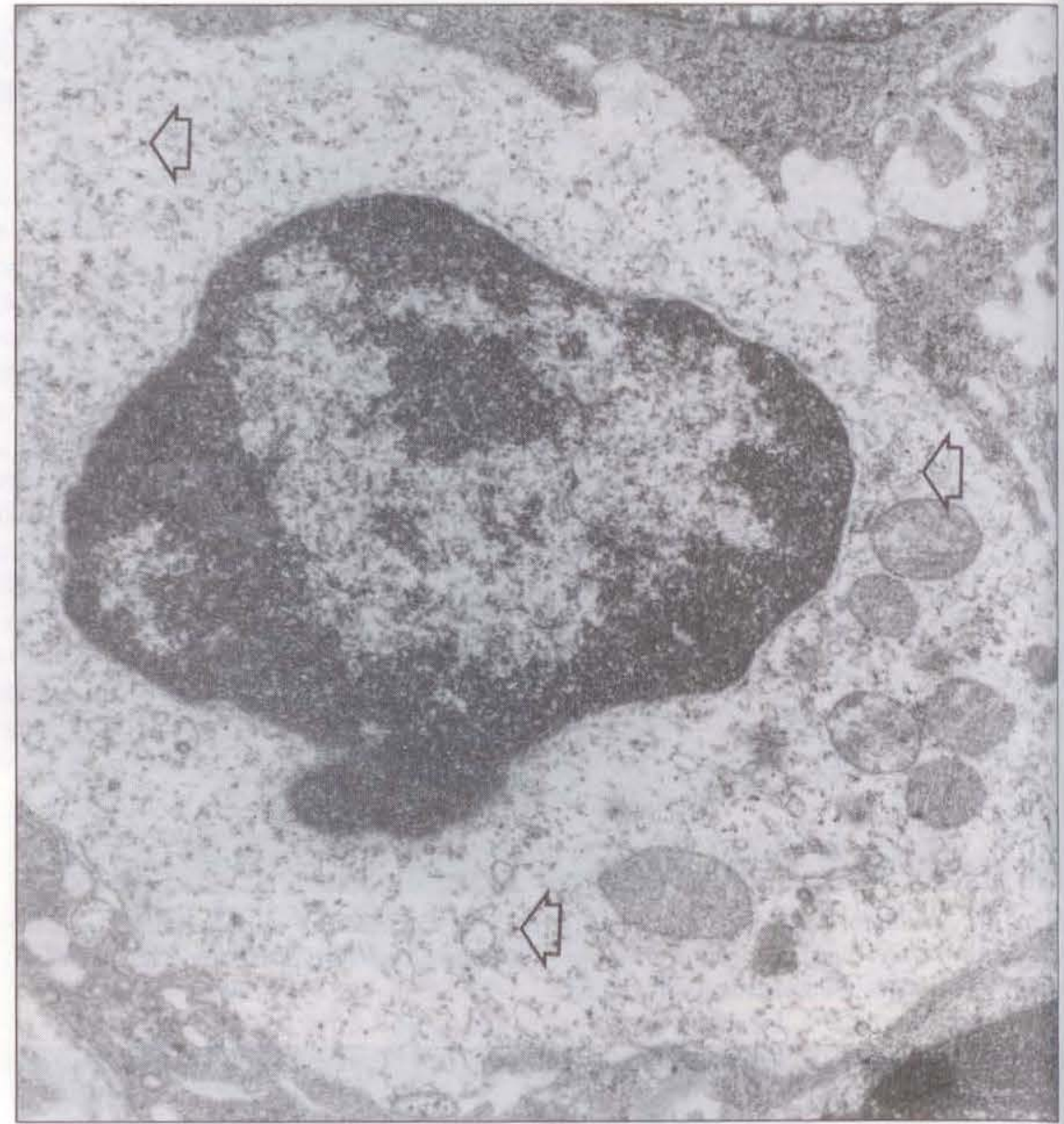

Figure 3) A 'resting' natural killer cell in the colonic epithelium of a control. The protein A conjugated $20 \mathrm{~nm}$ gold particles (arrows) are fixed to an anti-leucine-11 (CD16) monoclonal antibody specific for natural killer cells $\times 14,350$

significant amelioration of his disease was achieved. Biopsy results confirmed remission. Histology revealed the occurrence of natural killer cells in the colonic epithelium (average number of natural killer cells $7.5 / \mathrm{mm}^{2}$ ). The patient has now been treated for four months with interferon-alpha-2a and remains in full remission. He gained 8.5 $\mathrm{kg}$ and his current CDAI is 80 . The perianal lesion is almost completely closed and he has been discharged from the hospital. Treatment with interferon-alpha-2a will be continued using the same dose and schedule for another two months. Following this period, the interferon-alpha-2a will be administered once a week at the same dose of 3 Mu given subcutaneously.

\section{DISCUSSION}

Previous studies of IBD have used in vitro procedures with cells isolated from intestinal tissue or peripheral blood $(2-5,7,11,12)$. These cells may be only a small subset of the lymphoid population that occur in the gut, and they probably are not representative of the actual number and types of cells present in situ (13). Therefore, it is imperative to compare the in situ cel. lular composition of intestinal lympho. cytes from normal and IBD patients in order to obtain a better idea of the ac. tual conditions encountered during an inflammatory response in the gut.

The number of natural killer cells in peripheral blood and in the intestine was similar in patients with IBD and normal individuals $(5,6,12,13)$. Several groups have recently reported a significantly lower level of activity in both natural killer cells and antibody-dependent cellular cytotoxicity in IBD patients $(2-4,14,15)$. The authors have detected a decreased number of natural killer cells within the colonic epithelium of children with Crohn's dis- 
ease or severe ulcerative colitis (pancolitis) independent of the activity of the disease. A decrease in the number of natural killer cells may represent a possible primary etiological factor of IBD. This phenomenon appears to be a localized problem occurring only in the colonic epithelium of patients with IBD. Consequently, it may lead to a defect in the immunological response of these individuals.

Natural killer cell activity has been found to be inhibited in IBD patients who have been treated with sulphasalazine (16). This effect seems to be reversible, although it is not as apparent in patients who have been treated with 5-ASA (16).

Natural killer cells isolated from peripheral blood had decreased activities seemingly independent of treatment; this decreased activity has been attributed to a defect in the maturation process of natural killer cells in patients with IBD (2). A lack of natural killer cells that was independent of treatment was also observed which was in agreement with Hayashi et al (2). In contrast to the observations found in IBD patients, patients with left-sided ulcerative colitis who were in remission had a normal number of natural killer cells present in the epithelium of the gut. This may serve as an indication of the activity of ulcerative colitis; alternatively, it may distinguish between two groups of patients with distinctly different etiologies.

Several immunological mediators have been used to alleviate an inflammatory response. Interferon-gamma is capable of enhancing the activity of natural killer cells isolated from peripheral blood in normal and IBD patients $(3,14)$. However, the enhancement of natural killer cell activity in IBD patients was significantly reduced, which indicates that there may be a primary defect in the natural killer cells of patients with $\operatorname{IBD}(3,14)$. In general, interferons alpha and gamma enhance cytotoxic activity of natural killer cells and neutrophils (17). Interferon-gamma is known to stimulate the growth of $B$ and $T$ lymphocytes and to initiate differentiation of B cells (17). Furthermore, inter- feron-gamma up-regulates major histocompatibility complex (MHC) class II antigens (18). Interferon-gamma as a therapeutic agent in Crohn's disease in adults has had only a limited efficacy $(4,19,20)$. A possible explanation for its minimal therapeutic effect may be attributed to the fact that interferongamma has little down-regulating effect on interleukin-1 (17). Therefore, the reduction of interleukin-1 synthesis may provide an additional anti-inflammatory influence in patients with IBD. Consequently, interferon-alpha was used to down-regulate interleukin-1, to limit the stimulation of $\mathrm{MHC}$ class II antigens, to enhance cytotoxic and cytostatic activity, and to induce antiviral activity. Interferon-alpha also has a negative influence on antibody and hypersensitivity responses and increases MHC class I antigens (17); its presence, accordingly, may further ameliorate the inflammatory status of patients with IBD. Furthermore, interferon-alpha but not interferon-gamma is known to be a potent stimulator of natural killer cell activity $(21,22)$.

At present there are no data pertaining to interferon-alpha's role with natural killer cells and impact on the inflammatory course of IBD. Therefore, the present observations of an increased number of natural killer cells concomitant with an amelioration of ulcerative colitis following interferonalpha-2a treatment is of particular importance. It demonstrates that interferon-alpha-2a has either a proliferative effect and/or a chemotactic effect on natural killer cells. Consequently, by increasing MHC class I antigen expression, or by enhancing the recognition of antigen by natural killer cells, these and other possible immunomodulating effects by interferon-alphaZa may be responsible for inducing remission in ulcerative colitis (17).

In addition to the usual labelling of CD16 on the cell surface of natural killer cells by a monoclonal antibody (anti-leucine-11), these antigens were internalized by the cell into granules located in the cytoplasm. This phenomenon may be an indication of an activation pathway for natural killer cells that is similar to one recently reported for murine T cells (EL-4 cell line). Curtis et al (23) suggested that the internalization of the cell surface receptor complex for interleukin-1 was correlated with interleukin-1 signal transduction events required to induce growth factor production. The subsequent transport of the internalized complex to the nucleus suggests the possibility of a nuclear site for signalling. Indeed, an analysis of natural killer cell cytoplasm revealed characteristic granules scattered throughout the cytoplasm that were usually localized around the nuclear notch (24). Perhaps these granules with natural killer cell receptors are involved in a signal transduction pathway that leads to cell proliferation and/or to homing of natural killer cells within the epithelium of the gut.

Finally, one additional major biological function of natural killer cells should be emphasized. These cells have an important role in recognizing tumour antigens and thereby eliminating tumour cells (7). Therefore, by enhancing the number of natural killer cells, the risk of neoplasia in a patient with IBD can be significantly reduced. This correlates well with the observation that patients with left-sided colitis have a significantly lower risk for developing neoplasia (25); this lower risk may be due to the presence of natural killer cells in the colonic epithelium.

ACKNOWLEDGEMENTS: The authors express their gratitude to the Falk Foundation of Freiburg, Germany, and to Interfalk of Ettingen, Switzerland, for supporting in part the present study.

\section{REFERENCES}

1. Strober W, James SP. The immunologic basis of inflammatory bowel disease. J Clin Invest 1986;6:415-32.

2. Hayashi K, Hirata I, Orino S, et al. Natural killer (NK) activity and NK subsets in patients with inflammatory bowel disease. Jpn J Gastroenterol 1988;85:1240-4.

3. Müller Ch, Knoflach P, Smetana P, Meisinger V, Zielinski CC. Spontaneous and interferon-induced natural cytotoxicity in Crohn's disease.

Digestion 1988;39:26-34.

4. Kamoi S, Suzuki H, Yano Y, et al. 
Immunological studies on the patients with Crohn's disease and a new attempt of interferon treatment. Jpn J Gastroenterol 1989;86:193-9.

5. Raedler A, Schreiber S. Immunology of ulcerative colitis. Hepatogastroenterology 1989;36:213-8.

6. Arató A, Savilahti E, Tainio V-M, Klemola T. Immunohistochemical study of lymphoplasmacytic infiltrate and epithelial HLA-DR expression in the rectal and colonic mucosas of children with ulcerative colitis. J Pediatr Gastroenterol Nutr 1989;8:172-80.

7. Fiocchi C, Kusugami K, Trudel J, Leberman BY, Ouyang Q, El-Youssef M. Immunocytotoxicity and lymphokines in inflammatory bowel disease. In: Goebell H, Peskar BM, Malchow $\mathrm{H}$, eds. Inflammatory Bowel Diseases - Basic Research and Clinical Implications. Boston: MTP Press, 1988:113-20.

8. Rachmilewitz D. Coated mesalazine (5-aminosalicylic acid) versus sulphasalazine in the treatment of active ulcerative colitis: A randomized trial. Br Med J 1989;298:82-6.

9. Lucocq JM, Roth J. Applications of immunocolloids in light microscopy. III. Demonstration of antigenic and lectinbinding sites in semithin resin sections. J Histochem Cytochem 1984;32:1075. 83.

10. Maxwell MH. Two rapid and simple methods used for the removal of resins from $1.0 \mu \mathrm{m}$ thick epoxy sections. J Microsc 1978;112:253-5.

11. Brown TE, Bankhurst AD, Strickland
RG. Natural killer cell function and lymphocyte subpopulation profiles in inflammatory bowel disease. J Clin Lab Immunol 1983;11:113-7.

12. Okabe N, Fujita K, Yamasaki M, Yao $\mathrm{T}$, Tsuru S. Immunological studies on Crohn's disease. V. Enumeration of circulating lymphocyte subsets using monoclonal antibodies. Gastroenterol Jpn 1985;20:431-5.

13. Gibson PR, Jewell DP. Local immune mechanisms in inflammatory bowel dis ease and colorectal carcinoma. Natural killer cells and their activity. Gastroenterology 1986:90:12-9.

14. Knoflach P, Müller $\mathrm{CH}$, Zielinski CC. Deficient spontaneous and interferoninduced natural killer cell activity and antibody-dependent cellular cytotoxicity in Crohn's disease. In: Goebell $\mathrm{H}$, Peskar BM, Malchow H, eds. Inflammatory Bowel Diseases - Basic Research and Clinical Implications. Boston: MTP Press, 1988:387.

15. Ginsburg C, Dambrauskas JT, Ault K, Falchuk ZM. Impaired natural killer cell activity in patients with inflammatory bowel disease: Evidence for a qualitative defect. Gastroenterology 1983;85:846-51.

16. Aparicio-Pagés MN, Crama-Bohbouth GE, Verspaget HW, Peña AS, Weterman IT, Lamers CBHW. Inhibition of peripheral blood natural killer (NK) cell activity by in vitro treatment with salazosulphapyridine (SASP) but not with 5-aminosalicylic acid (5-ASA). Gut 1989;30:A720.

17. Balkwill FR. Peptide regulatory factors: Interferons. Lancet 1989;i:1060-3.
18. Ouyang Q, El-Youssef M, YenLieberman B, et al. Expression of HLA. DR antigens in inflammatory bowel disease mucosa: Role of intestinal lamina propria mononuclear cellderived interferon-gamma. Dig Dis Sci 1988;33:1528-36.

19. Vantrappen G, Coremans G, Billiau A, DeSomer P. Treatment of Crohn's disease with interferon: A preliminary clinical trial. Acta Clin Belg 1980;35:238-42.

20. Yoshida T, Higa A, Sakamoto $H$, et al. Immunological and clinical effects of interferon-gamma on Crohn's disease, J Clin Lab Immunol 1988;25:105-8.

21. Herberman RR, Ortaldo JR, Bonnard GD. Augmentation by interferon of human natural and antibody-depend. ent cell-mediated cytotoxicity. Nature 1979;277:221-3.

22. Rook AH, Kehrl JH, Wakefield LM, et al. Effects of transforming growth fac tor $A$ on the functions of natural killer cells: Depressed cytolytic activity and blunting of interferon responsiveness. J Immunol 1986;136:3916-20.

23. Curtis BM, Widmer MB, deRoos P, Qwarnstrom EE. IL-1 and its receptor are translocated to the nucleus. J Immunol 1990;144:1295-303.

24. Zarcone D, Prasthofer EF, Malavasi F, Pistoia V, LoBuglio AF, Grossi CE. Ultrastructural analysis of human natural killer cell activation. Blood 1987;69:1725-36.

25. Butt JH, Lennard-Jones JE, Ritchie JK A practical approach to the risk of cancer in inflammatory bowel disease. Med Clin North Am 1980;64:1203-6. 


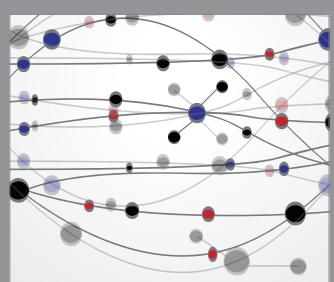

The Scientific World Journal
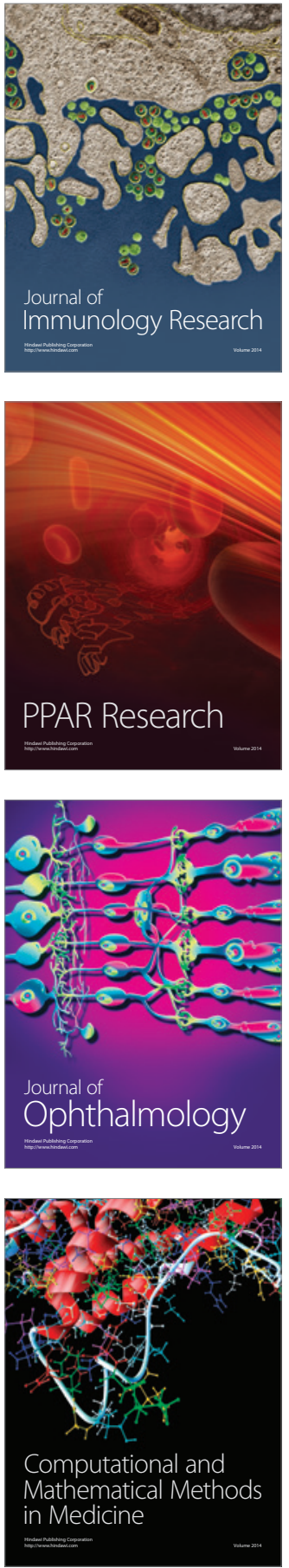

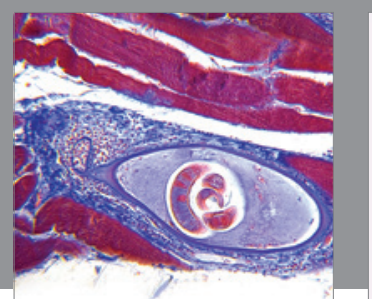

Gastroenterology Research and Practice

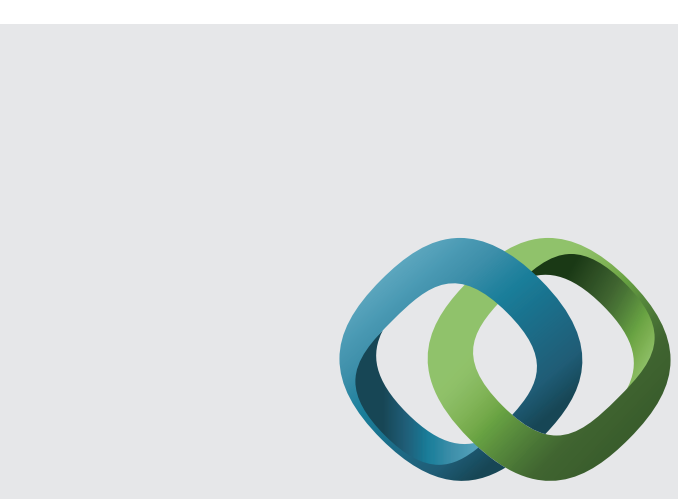

\section{Hindawi}

Submit your manuscripts at

http://www.hindawi.com
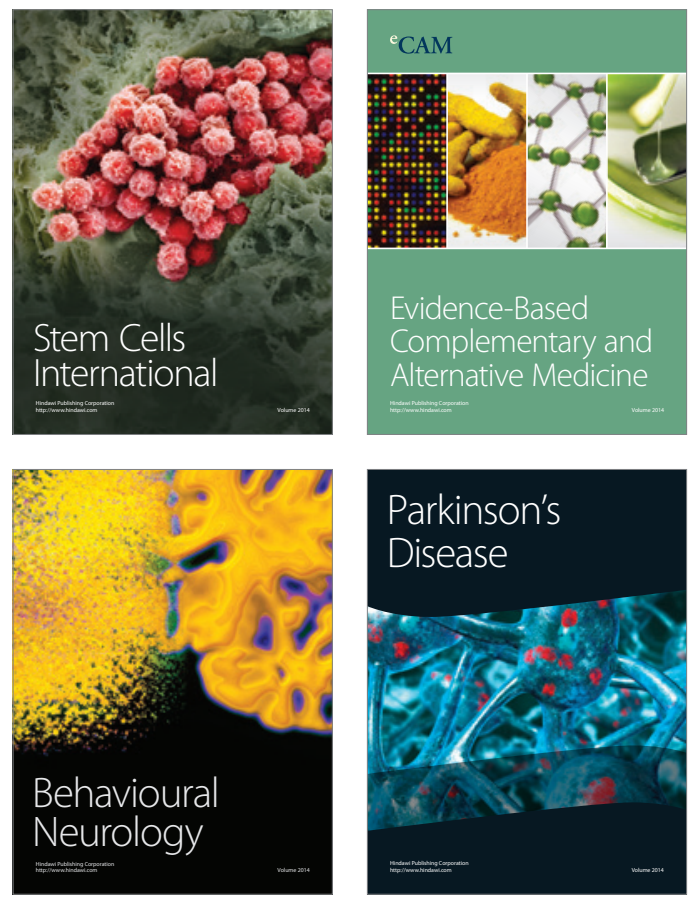
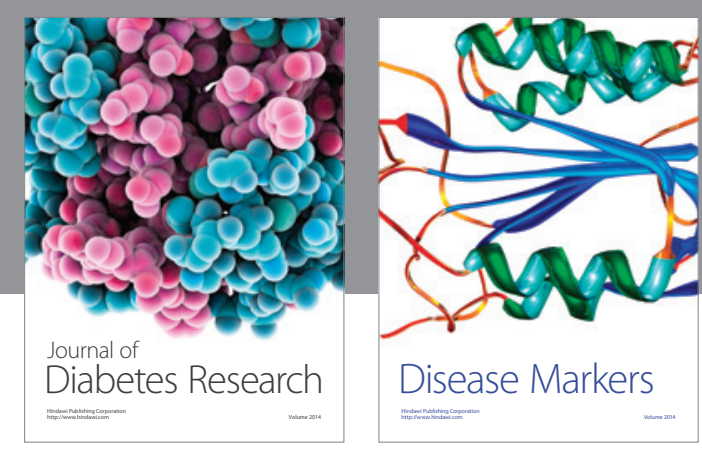

Disease Markers
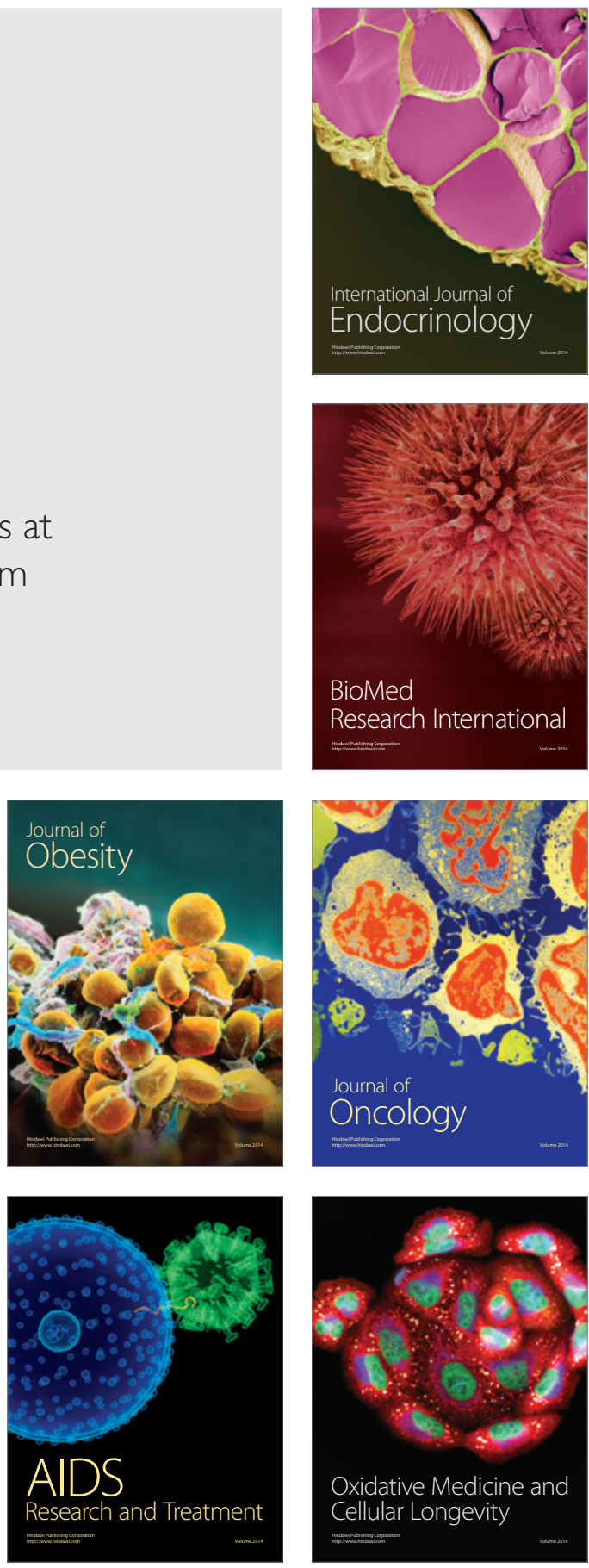